\title{
Advanced Oxidation Treatment of Composting Leachate of Food Solid Waste by Ozone-Hydrogen Peroxide
}

\author{
Maciej Gliniak*, Anna Lis', Daria Polek², Marta Wołosiewicz-Głąb² \\ 1 University of Agriculture in Krakow, al. Mickiewicza 21, 31-120 Krakow, Poland \\ 2 AGH University of Science and Technology, al. Mickiewicza 30, 30-059 Krakow, Poland \\ * Corresponding author's e-mail: maciej.gliniak@urk.edu.pl
}

\begin{abstract}
The research was conducted to investigate the efficiency and possibilities of advanced oxidation process based on ozone-hydrogen peroxide. The process was used as a post-treatment step of composting leachate utilisation. The leachate samples were collected from a typical composting plant with the aerobic biological treatment system. The samples were conditioned in a "ozone reactor" without dilution. The effectiveness of the treatment process was measured by $\mathrm{pH}$ values $(4.0-7.0), \mathrm{H}_{2} \mathrm{O}_{2}$ concentrations $\left(0.5-4.0 \mathrm{~g} \cdot \mathrm{dm}^{-3}\right)$, ozone doses $\left(0.5-1.5 \mathrm{~g} \cdot \mathrm{h}^{-1}\right)$ and reaction times $(0-10 \mathrm{~min})$. The highest removal efficiencies achieved were $85 \%$ and $92 \%$ for chemical oxygen demand $(\mathrm{COD})$ and biochemical oxygen demand $\left(\mathrm{BOD}_{5}\right)$, respectively. The optimum process parameters occurred at $\mathrm{pH}$ $5.0,2.0 \mathrm{~g} \cdot \mathrm{dm}^{-3}$ concentration of $\mathrm{H}_{2} \mathrm{O}_{2}$, and $0.75 \mathrm{~g} \cdot \mathrm{h}^{-1}$ of ozone dose. The optimal reaction time was $3 \mathrm{~min}$. The $\mathrm{O}_{3} /$ $\mathrm{H}_{2} \mathrm{O}_{2}$ advanced oxidation process was found to oxidize COD and $\mathrm{BOD}_{5}$ of the composting leachate. The oxidation reaction can be used as a feasible technique for composting leachate treatment.
\end{abstract}

Keywords: $\mathrm{BOD}_{5}$, $\mathrm{COD}$, oxidation, compost, leachate

\section{INTRODUCTION}

Food wastes (FW) are the main component of municipal solid waste (MSW). The estimates provided by Food and Agricultural Organization (2011), Carlson et al. (2012) and Zaman (2013) indicate increasing global food consumption and an over $40 \%$ increase in $\mathrm{FW}$ production by 2025. While analyzing the issues of the MSW economy, attention should be paid to the increase in the recycling of biodegradable waste. This process is related to the progressive reduction of storing in landfills waste that can be re-used (Wiliams, 2005).

One of the most popular FW recycling methods is composting. It belongs to the key technologies commonly used worldwide (Pitchel, 2010). Under temperate climate conditions, the composting process is divided into two stages, which in total should last for at least 8 weeks. The long duration time of the process depends on the choice of the composting method (active system with oxidation of the material or passive without oxidation) and the processed material type. On the basis of the research conducted in various countries, it was found that the first phase of the composting process should last approximately 2 weeks. Then, the material is directed to stabilization, which lasts 6-8 weeks. Currently, many studies in the field of optimization of the kinetics of the composting process in its first phase and the elimination of accompanying odorous substances are conducted globally (Lebrero et al., 2011; Yuan et al., 2015; Fernández et al., 2016; Jinyi et al., 2016; Siles et al., 2016; Yongjiang et al., 2016). In addition, in the literature on the subject there are studies on the additional hygienization of the stabilized material and the possibility of using gases generated during the process. One of the main problems associated with composting is the generation of the leachate containing material that has been extracted, suspended or dissolved in waste (Benlboukht et al., 2016; Junya et al., 2016; Lian et al., 2016; Mukesh et al., 2016). 
advanced oxidation processes (AOP)are very popular in current technologies of neutralization of fluid process residues. Most commonly, they are used to eliminate color, reduce the load of organic pollutants or reduce the toxicity of water and wastewater (Jia et al., 2011; Cortez et al., 2011). The principle of AOP is based on the release of hydroxyl radicals, which accelerate the degradation of organic compounds in the aquatic environment.

The most popular AOP is the $\mathrm{O}_{3} / \mathrm{H}_{2} \mathrm{O}_{2}$ system, which is used as a chemical process for purification and pre-treatment of wastewater (Maniero et al. 2008; Rosal et al., 2009; Liu et al., 2009; Quiang et al.; 2010). Tizaoui et al. (2007) obtained during the ozonization of the leachate the COD removal rate of $27 \%$ and the color reduction by 85\%. Rivas et al. (2003) and Hagman et al. (2008) received at least a $20 \%$ reduction in COD using only hydrogen peroxide $\left(\mathrm{H}_{2} \mathrm{O}_{2}\right)$. Using ozone along with the $\mathrm{H}_{2} \mathrm{O}_{2}$, a COD reduction of $20-50 \%$ can be achieved (Tizaoui et al., 2007; Hagman et al., 2008; Goi et al., 2009). The presented results refer to the application of the AOP system for wastewater. The leachates from the composting process are a more specific waste, the properties of which depend mainly on the oxygenation and moisture of the processed material.

The purpose of this article is to present the possibility of using the $\mathrm{O}_{3} / \mathrm{H}_{2} \mathrm{O}_{2}$ oxidation system in the process of preliminary preparation of the leachate from the FW composting process for neutralization in a professional wastewater treatment plant. The effectiveness of the process was assessed by the $\mathrm{BOD}_{5}$, $\mathrm{COD}$ dynamics of change and $\mathrm{BOD}_{5} / \mathrm{COD}$ ratio.

\section{MATERIAL AND METHODS}

\section{Leachate samples}

The leachate samples were prepared during the FW composting process in the BKB 100 isothermal bioreactor for the study of organic material decomposition processes. A FW mixture consisting of vegetables $(50 \%)$, fruit $(25 \%)$, expired food (15\%) and sawdust (10\%) with a total fresh weight of $50 \mathrm{~kg}$ was used for the tests. The composition of the mixture was selected to obtain appropriate structural properties of compost, while ensuring proper air flow in the bioreactor, biomass moisture during the process (54-68\%) and a $\mathrm{C}: \mathrm{N}$ ratio above 20 . In order to achieve a proper composting process and a distinct thermophilic phase, the air flow in the bioreactor was set at $0.035 \mathrm{~m}^{3} \cdot \mathrm{h}^{-1} \cdot \mathrm{kg}_{\mathrm{dw}}{ }^{-1}$ (which was $0.4 \mathrm{~m}^{3} \cdot \mathrm{h}^{-1}$ in the composted waste mass). During the process, a total of $3.3 \mathrm{dm}^{3}$ leachates were created.

\section{Experimental procedure}

The advanced leachate oxidation process was carried out in a flow glass reactor. The reactor is equipped with a stirrer, by means of which it is possible to aerate the mixture with the ozone coming from the discharge generator. Through the system of independent infusions, the leachates and the hydrogen peroxide solution are infused into the reaction chamber. The AOP procedure proceeded according to the following scheme:

1. Filling the reactor with $1 \mathrm{dm}^{3}$ of the leachate, which was mixed applying air with a capacity of $5.0 \mathrm{dm}^{3} \cdot \mathrm{min}^{-1}$ over a period of 5 minutes.

2. The AOP process involved:

a) Addition of $\mathrm{H}_{2} \mathrm{O}_{2}\left(1 \mathrm{~g} \cdot \mathrm{dm}^{-3}\right)$ and ozone $\left(1 \mathrm{~g} \cdot \mathrm{h}^{-1}\right)$, reaction time 10 minutes, regulation of the reaction using $1 \mathrm{~N}$ sodium hydroxide in the range of $4 \div 7$ (optimization of the reaction).

b) Differentiated $\mathrm{H}_{2} \mathrm{O}_{2}$ concentration at the optimal $\mathrm{pH}$ in the range of $0.5 \div 4 \mathrm{~g} \cdot \mathrm{dm}^{-3}$, ozone dose $1 \mathrm{~g} \cdot \mathrm{h}^{-1}$, reaction time -10 minutes.

c) Modification of ozone concentration in the range of $0.5 \div 1.5 \mathrm{~g} \cdot \mathrm{h}^{-1}$, reaction time $10 \mathrm{~min}$ utes, optimal $\mathrm{pH}$ and $\mathrm{H}_{2} \mathrm{O}_{2}$ concentration.

3. For each step presented in section 2, $\mathrm{pH}, \mathrm{COD}$, $\mathrm{BOD}_{5}, \mathrm{BOD}_{5} / \mathrm{COD}$ analyses were performed.

\section{Materials and analysis}

Hydrogen peroxide $(30 \%, \mathrm{w} / \mathrm{w})$ and sodium hydroxide solution $(1 \mathrm{~N})$ were of analytical reagent grade (Merck, Germany). Ozone was produced in the O3PRO30,7VW generator, equipped with a corona electrode system. The $\mathrm{pH}$ was measured by an Elmetron CP-511 conductometer with an EPS-1 glass electrode for the measurement of $\mathrm{pH}$ in the aqueous solution. COD was measured using a standard miniaturized method in airtight tubes, in accordance with the PN-ISO 15705:2005 standard. For the $\mathrm{BOD}_{5}$ measurement, the respirometric method described in DIN EN 1899 H55 was used, which uses OxiTop Control IS (WTW, Germany) for measurements. All experiments were carried out in 5 repetitions. During testing, the temperature was maintained at $22 \pm 1{ }^{\circ} \mathrm{C}$ and humidity at $55 \pm 5 \%$. 


\section{RESULTS}

The examined leachate samples were taken from the process of composting biodegradable waste in container technology. The basic leachate parameters were $36.9 \mathrm{~g} \cdot \mathrm{dm}^{-3}$ (COD), 19.7 $\mathrm{g} \cdot \mathrm{dm}^{-3}\left(\mathrm{BOD}_{5}\right)$ at $\mathrm{pH} 7.32$ and electrical conductivity $12.73 \mathrm{mS} \cdot \mathrm{cm}^{-1}$. The sample of the leachate was characterized by a black color and a sharp, irritating odor. The analyzed leachate samples have distinctively high level of oxygen demand, whereas the $\mathrm{BOD}_{5} / \mathrm{COD}$ ratio was 0.53 , which indicates a high potential of biodegradability of organic matter.

The values of $\mathrm{COD}$ and $\mathrm{BOD}_{5}$ at the $\mathrm{pH}$ of 5.0 reached maximum, which amounted to $26 \%$ and $31 \%$, respectively (Fig. 1). The efficiency of oxygen demand reduction fell above the $\mathrm{pH}$ value of 9.5 and remained stable. The Pearson correlation test showed a direct linear relationship between the $\mathrm{pH}$ values and COD removal efficiency $(\mathrm{P}<0.05, \mathrm{r}=0.817)$ and $\mathrm{BOD}_{5}(\mathrm{P}<0.05, \mathrm{r}=0.836)$.

The effect of various concentrations of $\mathrm{H}_{2} \mathrm{O}_{2}$ was examined in eight variants of concentration $0.5 \div 4 \mathrm{~g} \cdot \mathrm{dm}^{-3}$ with the ozonization efficiency of 1 $\mathrm{g} \cdot \mathrm{h}^{-1}$ (Fig. 2). The maximum degradation of COD and $\mathrm{BOD}_{5}$ was $42 \%$ and $49 \%$, respectively, at a concentration of $3.0 \mathrm{~g} \cdot \mathrm{dm}^{-3} \mathrm{H}_{2} \mathrm{O}_{2}$. A further increase in the $\mathrm{H}_{2} \mathrm{O}_{2}$ concentration caused slower degradation of both COD and $\mathrm{BOD}_{5}$. The Pearson correlation test showed a direct linear relationship between the $\mathrm{H}_{2} \mathrm{O}_{2}$ concentration and $\mathrm{BOD}_{5}$ removal efficiency $(\mathrm{P}<0.05, \mathrm{r}=0.728)$. At the same time, this test showed an inverse relationship between $\mathrm{H}_{2} \mathrm{O}_{2}$ concentration and COD removal, which was not significant $(\mathrm{P}<0.05, \mathrm{r}=-0.408)$.

The effect of the ozone dose on the removal of $\mathrm{COD}$ and $\mathrm{BOD}_{5}$ in the presence of an optimized dose of $\mathrm{H}_{2} \mathrm{O}_{2}$ and $\mathrm{pH}$ (5.0) caused a linear increase in the degradation of oxygen demand and constant reaction time (Fig. 3). The highest efficiency of COD removal (36\%) was achieved with 0.75 $\mathrm{g} \cdot \mathrm{dm}^{-3}$ ozone dose. Removal of $\mathrm{BOD}_{5}$ achieved the highest reduction at an analogous dose of ozone and amounted to $49 \%$. The above-mentioned results were achieved during a 10-minute reaction time.

In order to examine the effect of reaction time on the oxygen demand reduction efficiency, an experiment was carried out at variable reaction times of $0 \div 10$ minutes in the previously optimized doses of $\mathrm{H}_{2} \mathrm{O}_{2}$ and $\mathrm{O}_{3}$ (Fig. 4). The results showed that the increase in the reaction time linearly increases the efficiency of oxygen demand reduction. The maximum $\mathrm{COD}$ and $\mathrm{BOD}_{5}$ reduction values were $63 \%$ and $69 \%$, respectively, at 4 minutes. In the reaction time range of $6 \div 10$ minutes, the oxygen demand reduction efficiencies did not change significantly. The results of Pearson correlation test showed a direct linear relationship between the reaction time and the reduction efficiency of $\mathrm{BOD}_{5}(\mathrm{P}<0.05, \mathrm{r}=0.992)$ and $\operatorname{COD}(\mathrm{P}<0.05, \mathrm{r}=0.998)$.

The $\mathrm{BOD}_{5} / \mathrm{COD}$ ratio during the ozonization changes in time analogous to the variability of the reduced indicators. For the untreated samples, it reached 0.53. After taking into account the optimal process conditions, the $\mathrm{BOD}_{5} / \mathrm{COD}$ ratio amounted to 0.38 .

\section{DISCUSSION}

In the carried out study, stable results were obtained at lower $\mathrm{pH}$ values than described in 20-21. Figure 1 shows that a more stable

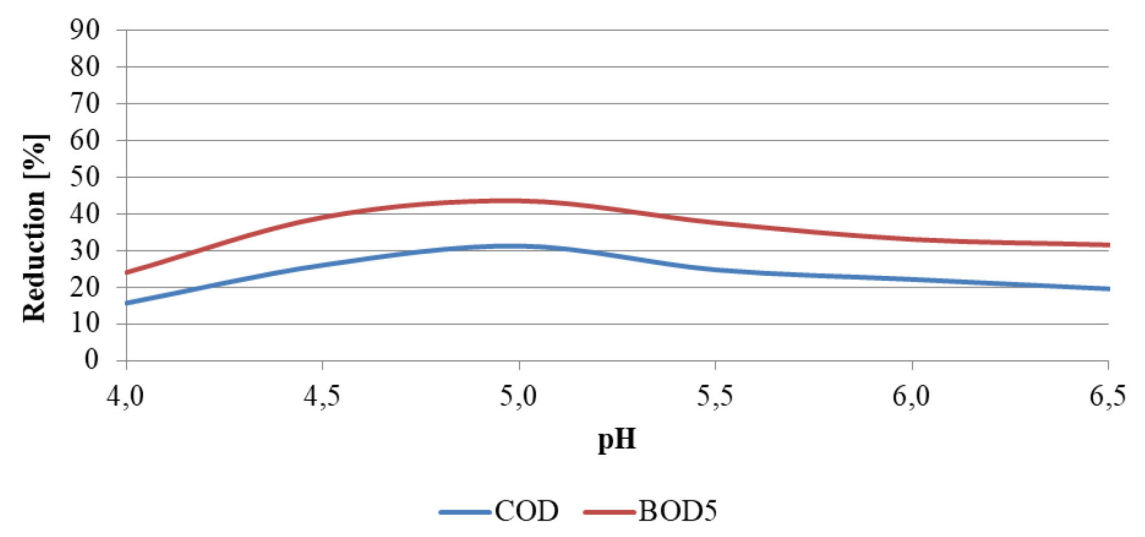

Fig. 1. Effect of the $\mathrm{pH}$ on $\mathrm{COD}$ and $\mathrm{BOD}_{5}$ removal $\left(\mathrm{H}_{2} \mathrm{O}_{2}\left[1.0 \mathrm{~g} \cdot \mathrm{dm}^{-3}\right], \mathrm{O}_{3}\left[1.0 \mathrm{~g} \cdot \mathrm{h}^{-1}\right]\right.$ and reaction time $\left.[10 \mathrm{~min}]\right)$ 
reduction in oxygen demand was achieved by leachate than in Cortez et al. (2011). The studies showed that the effect of using $\mathrm{H}_{2} \mathrm{O}_{2}$ positively influenced the efficiency of removing pollutants while using concentrations in the range of 1.5-2.5 $\mathrm{g} \cdot \mathrm{dm}^{-3}$. Cortez et al. (2011) noted the positive effect of using the $\mathrm{O}_{3} / \mathrm{H}_{2} \mathrm{O}_{2}$ system in relation to the ozonation alone. In his studies, he achieved a reduction of COD from $27 \%$ to $72 \%$ depending on hydrogen peroxide concentration.

Studies by Tizaoui et al. (2007) and Rivas et al. (2003) stated that the application of excessive doses of $\mathrm{H}_{2} \mathrm{O}_{2}$ adversely affects the process of wastewater treatment. This has also been confirmed in the carried out studies as illustrated in Figure 2. Tizaouni et al. (2007) received optimal process parameters at the hydrogen peroxide concentration $2 \mathrm{~g} \cdot \mathrm{dm}^{-3}$. With further increase in concentration (up to $6 \mathrm{~g} \cdot \mathrm{dm}^{-3}$ ) the process efficiency decreased by $6.5 \%$.

Ozone may participate in the generation of hydroxyl radicals. While increasing the concentration of $\mathrm{O}_{3}$ in the studied process, the COD and $\mathrm{BOD}_{5}$ removal rate improved (Fig. 3). Hydroxyl radicals that have not participated in wastewater treatment, together with ozone, increase the degradability of pollutants, confirming studies 24 . In the study by Maniero et al. (2008) a 70\% decrease in the COD value was obtained after the application of ozone at a dose of $9 \mathrm{~g} \cdot \mathrm{dm}^{-3}$. In analogous studies by Cortez et al. (2011) COD removal at $25 \%$ was achieved with the concentration of $\mathrm{O}_{3}$ in the range of $63-112 \mathrm{~g} \cdot \mathrm{dm}^{-3}$.

Reaction time is a key indicator of the wastewater treatment process. The conducted research has shown that the use of AOP effectively reduces the time needed to remove contaminants. At the same time, the positive, the synergistic effect of using oxidants on wastewater treatment, described by $8-20$, was confirmed. The achieved results of reducing the reaction time (Fig. 4), gave better results than those described in papers Lian et al. (2016) and Mukesh et al. (2016).

The presented research results show that the proper use of the $\mathrm{O}_{3} / \mathrm{H}_{2} \mathrm{O}_{2}$ oxidation system increases the biodegradability of wastewater. Similar results were obtained by Goi et al. (2009) during the leachate treatment using the Fenton reaction. In addition, during the process of contaminants oxidation, changes in the molecular structure of contaminants were achieved, as shown by the $\mathrm{BOD}_{5} / \mathrm{COD}$ indicator. By reducing the oxygen demand, a transformation of compounds that are difficult to biodegrade into more degradable forms has been achieved, which was also described by Jinyi et al. (2016) and Rivas at al. (2003).

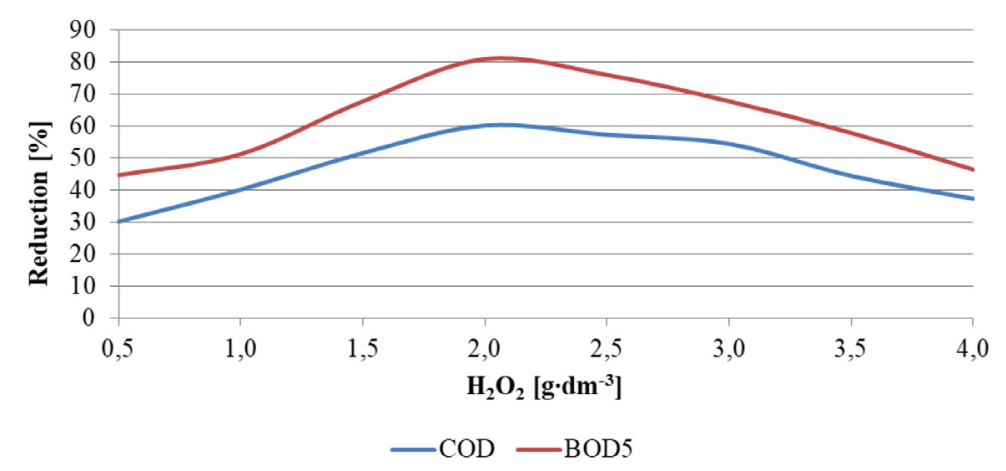

Fig. 2. Effect of the $\mathrm{H}_{2} \mathrm{O}_{2}$ on $\mathrm{COD}$ and $\mathrm{BOD}_{5}$ removal ( $\mathrm{pH}[5.0], \mathrm{O}_{3}\left[1.0 \mathrm{~g} \cdot \mathrm{h}^{-1}\right]$ and reaction time $\left.[10 \mathrm{~min}]\right)$

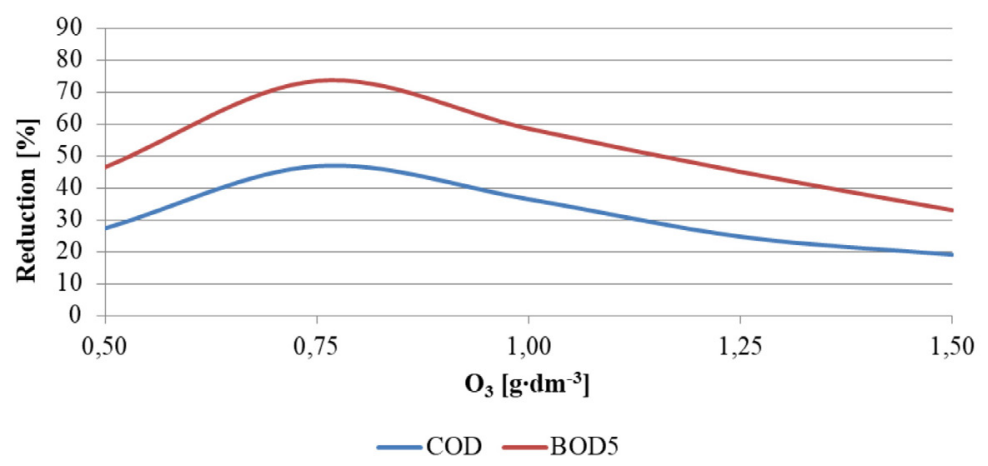

Fig. 3. Effect of the $\mathrm{O}_{3}$ on $\mathrm{COD}$ and $\mathrm{BOD}_{5}$ removal $\left(\mathrm{pH}[5.0], \mathrm{H}_{2} \mathrm{O}_{2}\left[3.0 \mathrm{~g} \cdot \mathrm{dm}^{-3}\right]\right.$ and reaction time $\left.[10 \mathrm{~min}]\right)$ 


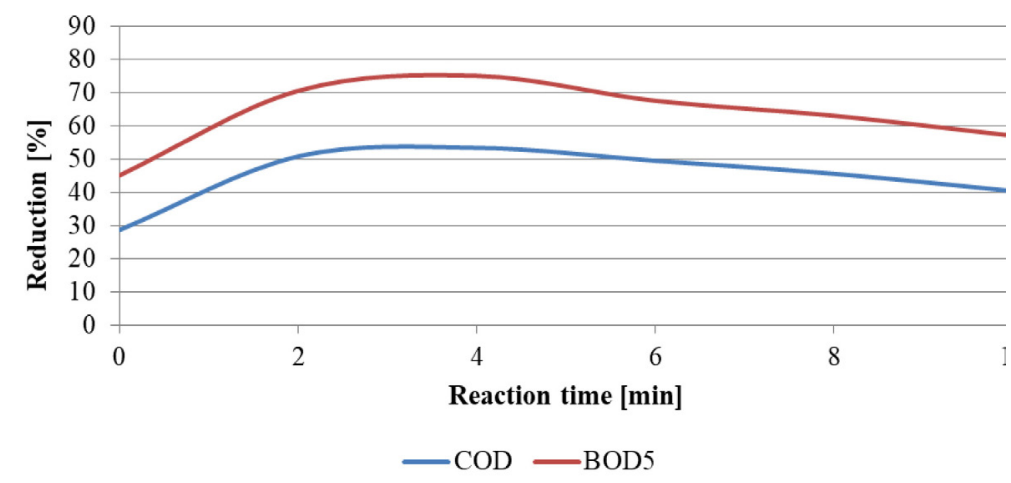

Fig. 4. Effect of the reaction time on $\mathrm{COD}$ and $\mathrm{BOD}_{5}$ removal $\left(\mathrm{pH}[5.0], \mathrm{H}_{2} \mathrm{O}_{2}\left[1.0 \mathrm{~g} \cdot \mathrm{dm}^{-3}\right]\right.$ and $\left.\mathrm{O}_{3}\left[0.75 \mathrm{~g} \cdot \mathrm{h}^{-1}\right]\right)$

\section{CONCLUSION}

The results of the carried out tests clearly show that the combination of $\mathrm{H}_{2} \mathrm{O}_{2}$ and $\mathrm{O}_{3}$ in one oxidation system is an effective way to reduce the oxygen demand during leachate treatment. The optimum process conditions occur at the $\mathrm{pH}$ of 5.0 and the addition of oxidants at the level of $0.75 \mathrm{~g} \cdot \mathrm{dm}^{-3}$ each. The optimal and reasonable reaction time is 4 minutes. The test results indicate the beneficial effect of AOP on process leachates, reducing the $\mathrm{BOD}_{5} / \mathrm{COD}$ ratio by $30 \%$, thus - lowering the oxygen demand during the treatment. The use of this reaction, due to the high biodegradability of leachates from the composting process, can be a preparatory process before transferring them to a wastewater treatment plant.

\section{Acknowledgements}

Publication was financed by the Ministry of Science and Higher Education of the Republic of Poland - statutory activity no. BM-4639 and DS3600/WIPiE/2018.

Publication supported by the Polish Ministry of Science and Higher Education as a part of the program of activities disseminating science from the project „Organization of the First International Science Conference - Ecological and Environmental Engineering”, 26-29 June 2018, Kraków.

\section{REFERENCES}

1. Benlboukht F., Lemee L., Amir S., Ambles A., Hafidi M. 2016. Biotransformation of organic matter during composting of solid wastes from traditional tanneries by thermochemolysis coupled with gas chromatography and mass spectrometry. Eco- logical Engineering, 90, 87-95.

2. Carlsson M., Lagerkvist A., Morgan-Sagastume F. 2012. The effects of substrate pretreatment on anaerobic digestion: a review. Waste Management, $32,1634-1650$.

3. Cortez S., Teixeira P., Oliveira R., Mota M. 2011. Evaluation of Fenton and ozone-based advanced oxidation processes as mature landfill leachate pretreatments. Journal of Environmental Management, 92, 749-755.

4. DIN EN 1899 H55. 1998. Water quality - Determination of biochemical oxygen demand after $\mathrm{n}$ days (BODn) - Part 2: Method for undiluted samples. International Organization for Standardization.

5. Fernández C., Mateu C., Moral R., Sole-Mauri F., 2016. A predictor model for the composting process on an industrial scale based on Markov processes. Environmental Modelling \& Software, 79, 156-166.

6. Food and Agricultural Organization. 2011. Global Food Losses and Food Waste - Study Conducted for the International Congress. Swedish Institute for Food and Biotechnology.

7. Goi A., Veressinina Y., Trapido M. 2009. Combination of ozonation and the Fenton processes for landfill leachate treatment: Evaluation of treatment efficiency. Ozone: Science \& Engineering, 31, 28-36.

8. Hagman M., Heander E., Jansen J.L. 2008. Advanced oxidation of refractory organics in leachate - Potential methods and evaluation of biodegradability of the remaining substrate. Environmental Technology, 29, 941-946.

9. Jia C., Wang Y., Zhang C., Qin Q. 2011. UV-TiO2 photocatalytic degradation of landfill leachate. Water, Air, \& Soil Pollution, 217, 375-385.

10. Jinyi G., Guangqun H., Jing H., Jianfei Z., Lujia H. 2016. Manure--wheat straw composting: A new approach that considers surface convection. International Journal of Heat and Mass Transfer, 97, 735-741.

11. Junya Z., Meixue Ch., Qianwen S., Juan T., Chao J., Xueting L., Yuxiu Z., Yuansong W. 2016. Im- 
pacts of addition of natural zeolite or a nitrification inhibitor on antibiotic resistance genes during sludge composting. Water Research, 91, 339-349.

12. Lebrero R., Rodríguez E., García-Encina P., A., Muñoz R. 2011. A comparative assessment of biofiltration and activated sludge diffusion for odour abatement. Journal of Hazardous Materials, 190(1-3), 622-630.

13. Lian Y., Shihua Z., Zhigiang Ch., Qinxue W., Yao W. 2016. Maturity and security assessment of pilot-scale aerobic co-composting of penicillin fermentation dregs (PFDs) with sewage sludge. Bioresource Technology, 204, 185-191.

14. Liu H., Liang M.Y., Liu C.S., Gao Y.X., Zhou J.M. 2009. Catalytic degradation of phenol in sonolysis by coal ash and $\mathrm{O} 3 / \mathrm{H} 2 \mathrm{O} 2$. Chemical Engineering Journal, 153, 131-137.

15. Maniero M.G., Bila D.M., Dezotti M. 2008. Degradation and estrogenic activity removal of 17 betaestradiol and 17alpha-ethinylestradiol by ozonation and $\mathrm{O} 3 / \mathrm{H} 2 \mathrm{O} 2$. Science of the Total Environment, 407, 105-115.

16. Mukesh K.A., Akhilesh K.P., Pushpendra S.B., Wong W.C., Li R., Zengqiang Z. 2016. Co-composting of gelatin industry sludge combined with organic fraction of municipal solid waste and poultry waste employing zeolite mixed with enriched nitrifying bacterial consortium. Bioresource Technology, 213, 181-189.

17. Pichtel J. 2010. Waste Management Practices: Municipal, Hazardous, and Industrial, second edition. Taylor and Francis, New York.

18. PN-ISO 15705. 2002. Water quality - Determination of the chemical oxygen demand index (ST-COD) - Small-scale sealed-tube method. International Organization for Standardization.

19. Qiang Z., Liu C., Dong B., Zhang Y. 2010. Degradation mechanism of alachlor during direct ozo- nation and $\mathrm{O} 3 / \mathrm{H} 2 \mathrm{O} 2$ advanced oxidation process. Chemosphere, 78, 517-526.

20. Rivas F.J., Beltrán F., Gimeno O., Acedo B., Carvalho F. 2003. Stabilized leachates: Ozone-activated carbon treatment and kinetics. Water Research, 37, 4823-4834.

21. Rosal R., Rodríguez A., Perdigón-Melón J.A., Petre A., García-Calvo E., 2009. Oxidation of dissolved organic matter in the effluent of a sewage treatment plant using ozone combined with hydrogen peroxide (O3/H2O2). Chemical Engineering Journal, 149, 311-318.

22. Siles J.A., Vargas F., Gutiérrez M.C., Chica A.F., Martín M.A. 2016. Integral valorisation of waste orange peel using combustion, biomethanisation and co-composting technologies. Bioresource Technology, 211, 173-182.

23. Tizaoui C., Bouselmi L., Mansouri L., Ghrabi A. 2007. Landfill leachate treatment with ozone and ozone/hydrogen peroxide systems. Journal of Hazardous Materials, 140, 316-324.

24. Williams P.T. 2005. Waste Treatment and Disposal. John Wiley and Sons, second edition, Great Britain.

25. Yongjiang W., Li P., Xinyu L., Yuansheng W., Kexun Z., Fei L. 2016. Using thermal balance model to determine optimal reactor volume and insulation material needed in a laboratory-scale composting reactor. Bioresource Technology, 206, 164-172.

26. Yuan J., Yang Q., Zhang Z., Li G., Luo W., Zhang D. 2015. Use of additive and pretreatment to control odors in municipal kitchen waste during aerobic composting. Journal of Environmental Sciences, 37, 83-90.

27. Zaman A.U. 2013. Identification of waste management development drivers and potential emerging waste treatment technologies. International Journal of Environmental Science and Technology, 10(3), $455-464$. 